\title{
Karolina Ziółkowska
}

Uniwersytet Mikołaja Kopernika, Torun

karolinaziolkowska17@wp.pl

\section{Uznanie zdarzenia za wypadek przy pracy przez organ rentowy w sprawie zawisłej przed sądem powszechnym}

DOI: http://dx.doi.org/10.12775/SIT.2017.018

Każdy pracownik czy też osoba, która podlega ubezpieczeniom społecznym, w tym ubezpieczeniu wypadkowemu, jest uprawniona do uzyskania świadczeń w związku $\mathrm{z}$ wypadkiem przy pracy, któremu uległa. Organem właściwym w tych sprawach jest organ rentowy, a więc np. Zakład Ubezpieczeń Społecznych (dalej ZUS), który o danych uprawnieniach ubezpieczonego w sprawach wypadkowych rozstrzyga w drodze decyzji administracyjnej. Od decyzji wydawanych przez ZUS przysługuje odwołanie do właściwego sądu w terminie i zgodnie $z$ zasadami określonymi w kodeksie postępowania cywilnego ${ }^{1 .} \mathrm{W}$ sprawach wypadkowych sądem właściwym jest sąd rejonowy zgodnie $\mathrm{z}$ art. $477^{8} \S 2$ kodeksu postępowania cywilnego ${ }^{2}$. Takie szczególne uregulowanie prawa do złożenia odwołania od decyzji administracyjnych sprawia, iż w chwili wniesienia odwoła-

${ }^{1}$ Art. 83 ust. 2 ustawy o systemie ubezpieczeń społecznych z dnia 13 października 2002 r. (Dz.U. z 2016 r. Poz. 963), zwana dalej ustawą o s.u.s., ustawą systemową.

${ }^{2}$ Tekst jednolity: Dz.U. z 2014 r. Poz. 101 ze zm., dalej k.p.c. 
nia przez stronę za pośrednictwem organu rentowego sprawa rozpatrywana jest przez sąd powszechny w postępowaniu cywilnym, które zostało na dodatek uregulowane jako postępowanie odrębne. W związku $z$ tym przekazanie przez organ odwołania wraz z aktami w przepisanym terminie powoduje, że przed sądem powszechnym organ rentowy nie jest już gospodarzem postępowania, lecz stroną pozwaną.

\section{Wypadek przy pracy}

Definicję legalną wypadku przy pracy znajdujemy w art. 3 ust. $1^{3}$ zgodnie, $z$ którym za wypadek przy pracy uważa się nagłe zdarzenie wywołane przyczyną zewnętrzną powodujące uraz lub śmierć, które nastąpiło w związku z pracą:

1) podczas lub w związku $z$ wykonywaniem przez pracownika zwykłych czynności lub poleceń przełożonych;

2) podczas lub w związku $z$ wykonywaniem przez pracownika czynności na rzecz pracodawcy, nawet bez polecenia;

3) w czasie pozostawania pracownika w dyspozycji pracodawcy w drodze między siedzibą pracodawcy a miejscem wykonywania obowiązku wynikającego ze stosunku pracy.

Pojęcie wypadku przy pracy w rozumieniu ustawy wypadkowej uznaje za wypadek przy pracy zdarzenie, które jednocześnie spełnia następujące kryteria: jest nagłe, wywołane przyczyną zewnętrzną, powodujące uraz lub śmierć oraz pozostaje w związku z pracą ${ }^{4}$ Ponadto musi istnieć związek przyczynowy danego zdarzenia $z$ pracą. W sposób domniemany można przyjąć, że istnieje związek przyczynowy przy istnieniu również związku czasowego, co oznacza iż zdarzenie miało miejsce w czasie przeznaczonym na pracę, oraz

${ }^{3}$ Ustawa $\mathrm{z}$ dnia 30 października 2002 r. o ubezpieczeniu społecznym $\mathrm{z}$ tytułu wypadków przy pracy i chorób zawodowych (Dz.U. z 2015 r. Poz. 1242 ze zm.), zwana dalej ustawą wypadkową.

${ }^{4} \mathrm{~S}$. Samol, Komentarz do art. 3 ustawy o ubezpieczeniu społecznym z tytutu wypadków $w$ przy pracy $i$ chorób zawodowych, w: Ustawa o ubezpieczeniu społecznym z tytułu wypadków przy pracy i chorób zawodowych. Komentarz, red. D. E. Lach, S. Samol, K. Ślebzak, Warszawa 2010, s. 32. 
związek miejscowy, co oznacza że zdarzyło się ono w miejscu pracy ${ }^{5}$. Zatem związek miejscowy i czasowy wypadku w pracy sprowadza się do ustalenia, czy zdarzenie wystąpiło w czasie pracy w znaczeniu prawnym (nie tylko w czasie efektywnego świadczenia pracy, ale również w czasie pozostawania w dyspozycji pracodawcy - art. 128 $\S 1$ k.p.) bądź w miejscu zakreślonym strefą zagrożenia stwarzanego przez pracę (na terenie zakładu pracy, a nie tylko w miejscu wykonywania czynności przez danego pracownika - art. 207 k.p.), przez powiązanie doznania uszczerbku na zdrowiu $z$ faktem wykonywania przez pracownika określonych czynności ${ }^{6}$.

Wszystkie przesłanki, aby dane zdarzenie zostało uznane za wypadek przy pracy, muszą zostać spełnione kumulatywnie. W związku z tym wypadkiem przy pracy nie będzie zdarzenie, które nie zostało wywołane przyczyną zewnętrzną, nie nastąpiło podczas pracy lub w związku z nią. Dlatego też wręczenie pracownikowi wypowiedzenia umowy o pracę i nagłe pogorszenie się $z$ tego powodu stanu jego zdrowia nie jest wypadkiem przy pracy w pojęciu art. 6 Ustawy z dnia 12 czerwca 1975 r. o swiadczeniach z tytułu wypadków przy pracy i chorób zawodowych (tekst jednolity: Dz.U. z 1983 r. Nr 30, poz. 144 ze zm.) ${ }^{7}$. Działania wykraczające poza zwykłe obowiązki pracownika mogą być uznane za podejmowane $\mathrm{w}$ interesie pracodawcy tylko wówczas, gdy mieszczą się w sferze uprawnień i obowiązków pracodawcy (art. 6 ust. 1 pkt 2 ustawy) ${ }^{8}$.

Natomiast odnosząc się do ostatniej przesłanki dotyczącej urazu lub śmierci, należy wskazać, iż dane zdarzenie może zostać uznane za wypadek przy pracy przy jednoczesnym ustaleniu w drodze orzeczniczej braku długotrwałego lub stałego uszczerbku na zdrowiu. Na mocy art. 16 ust. 1 zdanie pierwsze ustawy wypadkowej,

5 http://kadry.infor.pl/bhp/wypadki-w-pracy/219995,Jakie-zdarzeniekwalifikuje-sie-jako-wypadek-przy-pracy.html (dostęp: 9.09.2016 r.)

${ }_{6}^{6}$ Zob. wyrok SN z dnia 27 maja 2014 r., I PK 275/13, Lex nr 1477424.

7 Zob. wyrok SN z dnia 4 października 2000 r., I PKN 70/00, „Orzecznictwo Sądu Najwyższego. Izba Pracy i Ubezpieczeń Społecznych” 2002, nr 11, poz. 262.

8 Zob. wyrok SN z dnia 29 maja 2001 r., II UKN 374/00, „Orzecznictwo Sądu Najwyższego. Izba Pracy i Ubezpieczeń Społecznych” 2003, nr 4, poz. 104. 
uszczerbek na zdrowiu oraz jego związek $z$ wypadkiem przy pracy ustala lekarz orzecznik lub komisja lekarska.

\subsection{Protokół powypadkowy}

W sytuacji gdy u danego pracodawcy dochodzi do zdarzenia mającego znamiona wypadku przy pracy na mocy prawa, jest on zobligowany m.in. do ustalenia, w przewidzianym trybie, okoliczności oraz przyczyn tego wypadku (art. $234 \S 1$ k.p.).

Dalej w rozdziale VII kodeksu pracy (Dz.U. z 2016 r. Poz. 1053), którego tytuł brzmi „Wypadki przy pracy i choroby zawodowe”, na podstawie art. 237 k.p. znajduje się delegacja ustawowa do wydania przez Radę Ministrów aktu wykonawczego dotyczącego postępowania u danego pracodawcy w przypadku wypadków przy pracy ${ }^{9}$.

$\mathrm{Na}$ podstawie postanowień tego aktu pracodawca jest zobligowany do powołania zespołu powypadkowego, którego prace maja na celu ustalenie okoliczności i przyczyn wypadku. W jego skład wchodzi pracownik służby BHP oraz społeczny inspektor pracy (§ 4 rozporządzenia). Zespół powypadkowy sporządza w przepisanej formie protokół wypadkowy ${ }^{10}$ nie później niż w terminie $14 \mathrm{dni}$ od daty otrzymania zawiadomienia o nim. Odstępstwa od tego terminu zostały enumeratywnie wymienione w dalszych paragrafach omawianego rozporządzenia. Zespół powypadkowy na mocy $\S 12$ jest zobowiązany do szczegółowego uzasadnienia oraz wskazania na tę okoliczność dowodu m.in. w przypadku nieuznania zdarzenia za wypadek przy pracy.

Po sporządzeniu protokołu należy zapoznać z jego ustaleniami poszkodowanego. W przypadku kiedy sam pracodawca w protokole nie uznaje zdarzenia za wypadek przy pracy, pracownik ma prawo, zgodnie $z$ pouczeniem zawartym w protokole, przed Sądem

9 Rozporządzenie Rady Ministrów z dnia 1 lipca 2009 r. w sprawie ustalenia okoliczności i przyczyn wypadków przy pracy (Dz.U. z 2009 r. Nr 105, poz. 870).

${ }^{10}$ Wzór protokołu powypadkowego określa Rozporządzenie Ministra Gospodarski i Pracy z dnia 16 września 2004 r. w sprawie wzoru protokołu ustalenia okoliczności i przyczyn wypadku przy pracy (Dz.U. z 2004 r. Nr 227, poz. 2298). 
Rejonowym Wydział Pracy na podstawie art. 189 k.p.c., wytoczyć powództwo o ustalenie, czy dane zdarzenia ma charakter wypadku przy pracy ${ }^{11}$.

Protokół, który został zatwierdzony przez pracodawcę w trybie $\S 13$ pkt 1 wraz $z$ dokumentacją w sprawie, przekazywany jest do ZUS.

Konsekwencją nieprzedstawienia protokołu powypadkowego, nieuznania przez pracodawcę w protokole zdarzenia za wypadek przy pracy bądź w sytuacji gdy protokół zawiera stwierdzenia bezpodstawne, jest odmowa świadczeń $z$ ubezpieczenia wypadkowego w drodze decyzji wydanej przez ZUS ${ }^{12}$.

\section{2. Świadczenia $z$ ubezpieczenia wypadkowego}

Świadczeniami z ubezpieczenia wypadkowego oprócz jednorazowego odszkodowania $z$ tytułu uszczerbku na zdrowiu spowodowanego wypadkiem przy pracy jest również na podstawie art. 6 ust. 1 m.in. zasiłek chorobowy oraz świadczenie rehabilitacyjne. Oba te świadczenia przysługują w wysokości 100\% wymiaru podstawy (art. 9 ust. 1). W przypadku zasiłku chorobowego wypłacanego $z$ funduszu wypadkowego przysługuje on od pierwszego dnia niezdolności do pracy, a więc nie ma tutaj tzw. okresu wyczekiwania. Zgodnie $z$ art. 4 ust. $1^{13}$ ubezpieczony nabywa prawo do zasiłku chorobowego po upływie 30 dni nieprzerwanego ubezpieczenia chorobowego - jeżeli podlega obowiązkowo temu ubezpieczeniu, lub po upływie 90 dni nieprzerwanego ubezpieczenia chorobowego - jeżeli ubezpieczony jest dobrowolnie.

Przykład 1: Osoba, która wykonuje pracę na podstawie umowy zlecenia, a więc która podlega dobrowolnie ubezpieczeniu chorobo-

${ }^{11}$ Wyrok SN z dnia 16 marca 1999 r., II UKN 510/98, „Orzecznictwo Sądu Najwyższego. Izba Administracyjna, Pracy i Ubezpieczeń Społecznych” 2000, nr 9, poz. 366.

12 Art. 22 ust. 1 i 2 ustawy wypadkowej.

13 Ustawa $z$ dnia 25 czerwca 1999 r. o świadczeniach pieniężnych z ubezpieczenia społecznego w razie choroby i macierzyństwa (tekst jednolity: Dz.U. z 2016 Poz. 372), zwana dalej ustawą zasiłkową. 
wemu na podstawie art. 11 ust. 2 ustawy o s.u.s., $w$ przypadku orzeczenia okresowej niezdolności do pracy, która nie została spowodowana wypadkiem przy pracy, a niezdolność ta powstała w 31 dniu podlegania dobrowolnemu ubezpieczeniu chorobowemu, nie będzie miała prawa do zasiłku chorobowego $z$ funduszu chorobowego. Natomiast jeśli ta niezdolność powstałaby wskutek wypadku przy pracy, prawo do zasitku chorobowego przysługiwałoby od pierwszego dnia niezdolności.

Ponadto osoba wykonująca pracę na podstawie umowy cywilnoprawnej, np. zlecenia, podlega obowiązkowo ubezpieczeniu wypadkowemu w przeciwieństwie do ubezpieczenia chorobowego, które w przypadku tego tytułu do objęcia ubezpieczeniami społecznymi jest ubezpieczeniem dobrowolnym (art. 12 ust. 1 s.u.s.).

Przykład 2: W przypadku osoby, której tytuł do objęcia ubezpieczeniami społecznymi, $w$ tym ubezpieczeniem wypadkowym, stanowi umowa o pracę zawarta $z$ pracodawca, który zatrudnia powyżej 20 pracowników, a powstanie czasowej niezdolności do pracy nastapiło w 31 dniu, podlegania ubezpieczeniu chorobowemu. W takiej sytuacji wynagrodzenie chorobowe wyptacane jest na podstawie art. 92 k.p. w wysokości 80\% wymiaru podstawy przez okres 33 dni. Dopiero od 34 dnia trwania niezdolności do pracy przysługuje prawo do zasiłku chorobowego. W przypadku wystapienia czasowej niezdolności do pracy wskutek wypadku przy pracy od pierwszego dnia tej niezdolności przysługuje zasiłek chorobowy z funduszu wypadkowego w wymiarze 100\% wymiaru podstawy. W zależności od liczby zatrudnianych pracowników płatnikiem tego zasiłku jest albo pracodawca (powyżej 20 pracowników), albo ZUS.

\section{Postępowanie przed organem rentowym}

W momencie przekazania przez pracodawcę kompletu dokumentów wraz $z$ wnioskiem poszkodowanego pracownika o wyrównanie zasiłku chorobowego do wysokości 100\% wymiaru podstawy, przyznaniu świadczenia rehabilitacyjnego w związku $z$ wypadkiem przy pracy bądź wnioskiem o wypłatę jednorazowego odszkodowania z tytułu stałego lub długotrwałego uszczerbku na zdrowiu spowo- 
dowanego wypadkiem przy pracy, zostaje wszczęte postępowanie administracyjne. Zgodnie $z$ art. $61 \S 3$ kodeksu postępowania administracyjnego ${ }^{14}$ (dalej k.p.a.), datą wszczęcia postępowania na żądanie strony jest dzień doręczenia owego żądania organowi, w tym wypadku ZUS. Postępowanie to toczy się na mocy postanowień k.p.a. oraz ustaw szczególnych.

W pierwszej kolejności organ rentowy bada, czy zachodzą okoliczności wymienione w art. 22 ust. 1 ustawy wypadkowej. Zakład odmawia przyznania świadczeń $z$ ubezpieczenia wypadkowego w przypadku:

1) nieprzedstawienia protokołu powypadkowego lub karty wypadku;

2) nieuznania w protokole powypadkowym lub karcie wypadku zdarzenia za wypadek przy pracy w rozumieniu ustawy;

3) gdy protokół powypadkowy lub karta wypadku zawierają stwierdzenia bezpodstawne.

W takiej sytuacji nie jest prowadzone dalsze postępowanie, które miałoby na celu ustalenie przyczyny zewnętrznej zdarzenia. W przypadku, gdy w toku czynności ustalono, że zdarzenie było wywołane przyczyną zewnętrzną, organ rentowy na podstawie zebranego materiału dowodowego w sprawie zobowiązany jest do zbadania, czy nie zachodzą przesłanki określone w art. 21 ust. 1 i 2 ustawy wypadkowej, których stwierdzenie eliminuje przyznanie świadczeń związanych $z$ wypadkiem przy pracy. Jednakże konsekwencje utraty prawa do świadczeń nie dotyczą członków rodziny, którzy zachowują prawo do świadczeń $z$ ubezpieczenia wypadkowego ${ }^{15}$. Po zbadaniu tych okoliczności, jeśli nie zostanie stwierdzone przez organ rentowy, że wyłączną przyczyną wypadku przy pracy było udowodnione naruszenie przepisów dotyczących ochrony życia i zdrowia spowodowane przez daną osobę umyślnie lub wskutek rażącego niedbalstwa, podejmuje określone działania.

Jeśli ubezpieczony wystąpił o wypłatę zasiłku chorobowego $z$ ubezpieczenia wypadowego, wydawana jest w tej kwestii decyzja.

\footnotetext{
14 Tekst jednolity: Dz.U. z 2016 r. poz. 23.

15 M. Klimas, Postępowanie sądowe $w$ sprawach $z$ zakresu ubezpieczeń społecznych, Warszawa 2013.
} 
Natomiast w przypadku wniosku o ustalenie prawa do świadczenia rehabilitacyjnego $\mathrm{w}$ związku $\mathrm{z}$ wypadkiem przy pracy oraz wniosku o wypłatę jednorazowego odszkodowania sprawa kierowana jest wpierw do lekarza orzecznika ZUS. W zależności od wniosku, lekarz orzeka bądź o ustaleniu prawa do świadczenia rehabilitacyjnego w związku z wypadkiem przy pracy lub ustala czy ubezpieczony odniósł stały lub długotrwały uszczerbek na zdrowiu, jeśli tak, to w jakiej wysokości. Jeśli strona ${ }^{16}$ nie wniosła w terminie 14 dni sprzeciwu do Komisji Lekarskich ZUS, wydawana jest na podstawie takiego orzeczenia decyzja. W przypadku wniesienia sprzeciwu podstawą wydania decyzji jest orzeczenie Komisji Lekarskiej ZUS.

\subsection{Nieuznanie zdarzenia}

za wypadek przy pracy ze względu na

brak przyczyny zewnętrznej

Aby zacząć rozważania, należy wpierw wskazać, że nie istnieje definicja legalna pojęcia przyczyny zewnętrznej. Swego czasu pojęcie to w orzecznictwie sądów nastręczało wiele trudności, a w szczególności jego wąskie rozumienie, co w konsekwencji prowadziło do tego, że w wielu przypadkach zdarzenia mające miejsce w pracy, związane $z$ nią przyczynowo oraz czasowo nie były uznawane za wypadki przy pracy. Jednak obecnie w orzecznictwie został utrwalony pogląd dotyczący rozumienia przyczyny zewnętrznej. Przyczyną zewnętrzną wypadku może być każdy czynnik zewnętrzny, który jest zdolny wywołać w istniejących warunkach szkodliwe skutki, w tym także pogorszyć stan zdrowia pracownika dotkniętego już schorzeniem samoistnym ${ }^{17}$. W orzeczeniach Sądu Najwyższego utrwalił się pogląd, że co do zasady wykonywanie zwykłych, a więc typowych, normalnych, choćby stresujących lub wymagających dużego wysiłku

${ }^{16}$ Na podstawie art. 14 ust. 2 a ustawy o emeryturach i rentach z FUS z dnia 17 grudnia 1998 r., (Dz.U. z 2016 r. Poz. 887), zwana dalej ustawą emerytalną.

17 Zob. uchwała 7 sędziów SN z dnia 11 lutego 1963 r., III Po 15/62, „Orzecznictwo Sądu Najwyższego Izby Cywilnej, Pracy i Ubezpieczeń Społecznych" 1963, z. 10, poz. 215. 
fizycznego czynności (obowiązków) przez pracownika nie może być uznane za przyczynę zewnętrzną wypadku przy pracy, ponieważ sama praca nie może stanowić zewnętrznej przyczyny w rozumieniu legalnej definicji wypadku przy pracy, ale może nią być dopiero określona nadzwyczajna sytuacja związana $z$ tą pracą, która staje się współdziałającą przyczyną zewnętrzną ${ }^{18}$. Również przedstawiciele doktryny podkreślają złożoność problematyki rozumienia przyczyny zewnętrznej. Zaznaczyć należy, że przyczyna musi być jednocześnie źródłem urazu lub śmierci poszkodowanego pracownika, lecz nie musi być to tylko jedna przyczyna. W związku $\mathrm{z}$ czym $\mathrm{w}$ toku postępowania należy zbadać, czy możliwe jest istnienie tzw. przyczyny złożonej, istnienie czynnika zewnętrznego, który pokrył się z czynnikiem lub czynnikami wewnętrznymi istniejącymi już w organizmie poszkodowanego pracownika ${ }^{19}$. Takimi czynnikami wewnętrznymi mogą być np. choroby układu krążenia, tj. nadciśnienie, miażdżyca, choroba wieńcowa, różnego rodzaju patologie budowy mięśnia sercowego. Czynniki te będą zapewne oceniane przez biegłego lekarza kardiologa w sprawie wypadkowej, w której pracownik dostał zawału serca. Orzecznictwo wskazuje, że zawał serca może zostać uznany za przyczynę zewnętrzną wypadku przy pracy. Jednak okoliczności, przy jakich doszło do zdarzenia, którego skutkiem był zawał mięśnia sercowego, każdorazowo muszą zostać ustalone w postępowaniu dowodowym przed sądem powszechnym ${ }^{20}$.

Taką przyczynę wypadku przy pracy należy nazwać przyczyną mieszaną. W szczególności kiedy zarówno przez doktrynę, jak i orzecznictwo rozróżniania jest przyczyna zewnętrzna i przyczyna wewnętrzna, to w sytuacji kiedy występują jednocześnie obie te przyczyny, należy uznać, że mamy do czynienia z przyczyną mieszaną.

18 Zob. wyrok SN z dnia 18 marca 2015 r., I PK 162/14, LEX nr 1678949 oraz wyrok SN z dnia 4 listopada 2014 r., III UK 32/14, LEX nr 1628875.

19 S. Samol, op.cit., s. 33.

20 Zob. m.in. wyrok SN z dnia 6 maja 1976 r., III PZP 2/76, „Orzecznictwo Sądu Najwyższego Izby Cywilnej, Pracy i Ubezpieczeń Społecznych” 1976, z. 11, poz. 239. 


\section{Uznanie zdarzenia za wypadek po przekazaniu odwołania do sądu}

Na podstawie art. 83 ust. 7 ustawy o s.u.s. organ rentowy w ciagu 30 dni od daty wpływu odwołania jest zobowiązany przekazać je wraz $z$ aktami do właściwego sądu. Czas ten został również zakreślony na tzw. samokontrolę organu rentowego, a mianowicie na zmianę zaskarżonej decyzji w przypadku kiedy odwołanie zasługuje w całości na uwzględnienie. Jest to przepis szczególny w stosunku do art. 138 k.p.a., który zakreśla 7-dniowy termin na przekazanie akt sprawy. W związku z tym oczywiście ma tutaj zastosowanie zasada lex specialis derogat legi generali. W momencie przekazania sprawy do sądu następuje stan tzw. zawisłości sprawy.

Niesłuszne, a także pozbawione jakichkolwiek podstaw prawnych oraz racjonalności jest działanie organu polegające na wydaniu nowej decyzji dotyczącej tego samego roszczenia w sprawie zawisłej przed sądem powszechnym.

Przykład 3: W momencie wniesienia odwołania od decyzji odmawiajacej prawa do jednorazowego odszkodowania (brak przyczyny zewnętrznej zdarzenia) organ rentowy $w$ trybie samokontroli nie zmienia zaskarżonej decyzji. Odwołanie wraz $z$ aktami zostaje przekazane do właściwego sądu rejonowego. W trakcie postępowania sądowego organ rentowy stwierdza, że zdarzenie zostało wywołane przyczyna zewnętrzna, wskutek czego uznaje zdarzenie za wypadek przy pracy i kieruje wnioskodawce na badanie przez lekarza orzecznika ZUS, który ustala O\% uszczerbku na zdrowiu. Od powyższego orzeczenia zostaje wniesiony sprzeciw, a Komisja Lekarska podtrzymuje stanowisko orzecznika. Na podstawie tego orzeczenia organ rentowy wydaje decyzję o odmowie prawa do jednorazowego odszkodowania. Od decyzji tej oczywiście będzie przysługiwać odwołanie.

Analizując definicję wypadku, która została poczyniona na wstępie, oraz jego elementów składowych, należy wskazać, że przedmiotem każdej decyzji ZUS jest przyznanie bądź odmowa prawa do jednorazowego odszkodowania, bez względu na to, czy zdarzenie nie jest wypadkiem przy pracy czy też jest, którego następstwem 
nie jest stały lub długotrwały uszczerbek. Uszczerbek na zdrowiu nie stanowi pojęciowej cechy wypadku przy pracy, lecz ustawową przesłankę nabycia prawa do świadczeń wypadkowych ${ }^{21}$. Dlatego należy stać na stanowisku, że nawet uznanie zdarzenia za wypadek przy pracy w sprawie zawisłej przed sądem oraz ustalenie w ramach trybu orzeczniczego ZUS 0\% uszczerbku na zdrowiu nie daje podstaw organowi rentowemu do wydania nowej decyzji, ponieważ sytuacja prawna poszkodowanego nie zmienia się. W dalszym ciągu nie ma on prawa do jednorazowego odszkodowania $z$ tytułu wypadku przy pracy, o które spór toczy się już przed sądem powszechnym. Nadmienić należy, że samo uznanie zdarzenia za wypadek przy pracy nie jest uwzględnieniem żądania strony. Dlatego też nie jest możliwe umorzenie postępowania na podstawie art. $477^{13} \mathrm{k}$.p.c.

Zgodnie $z$ art. $477^{13} z$ d. 1 k.p.c. zmiana przez organ rentowy zaskarżonej decyzji przed rozstrzygnięciem sprawy przez sąd przez wydanie decyzji uwzględniającej w całości lub części żądanie strony - powoduje umorzenie postępowania w całości lub części. Sytuacja, o której mowa w przytoczonym przepisie, zaszłaby jedynie w momencie, kiedy po wniesieniu odwołania do sądu, organ rentowy uznałby zdarzenia za wypadek przy pracy, ustalił uszczerbek na zdrowiu oraz ustalił wysokość jednorazowego odszkodowania. Jest to również pozbawione jakiejkolwiek racjonalności, ponieważ polski ustawodawca, którego oczywiście racjonalność należy domniemać, dał możliwość zmiany decyzji w ramach samokontroli organu, dodatkowo wydłużając termin w przepisie szczególnym.

W świetle przedstawionych rozważań możliwe jest jedynie wydanie postanowienia o umorzeniu postępowania, ale na podstawie art. $355 \S 1$ k.p.c., w chwili kiedy strona odwołująca się cofnęłaby takowe odwołanie, zanim sąd wydałby wyrok bądź organ rentowy zmienił swoje stanowisko i uznał zdarzenie za wypadek przy pracy w sprawie zawisłej przed sądem powszechnym. To odwołujący się jest jedynym dysponentem odwołania ${ }^{22}$ i osobą decyzyjną, która

${ }^{21}$ Zob. wyrok SN z dnia 27 września 2000 r., II UKN 734/99, „Orzecznictwo Sądu Najwyższego Izba Pracy, Ubezpieczeń Społecznych i Spraw Publicznych” 2002, nr 8, poz. 193.

${ }^{22}$ E. Stefańska, Postępowanie z zakresu ubezpieczeń społecznych, w: Kodeks 
w każdej chwili może cofnąć swoje odwołanie zarówno przed sądem I instancji, jak i sądem odwoławczym czy nawet podtrzymywać je, chociażby było bezzasadne. W powyższym przepisie doktryna zwraca uwagę na sformułowanie, że wydanie wyroku stało się zbędne lub niedopuszczalne, co oznacza, iż przyczyna umorzenia zaistniała po wniesieniu odwołania przez stronę ${ }^{23}$. Natomiast niedopuszczalne jest w postępowaniu sądowym toczącym się $z$ odwołania ubezpieczonego w sprawie wypadkowej, umorzenie postępowania ze względu na to, że stało się ono $z$ innych przyczyn zbędne lub niedopuszczalne. W doktrynie przyjmuje się, że taka sytuacja zachodzi, jeśli w danej sprawie została zawarta ugoda między stronami. Natomiast art. $477^{12}$ k.p.c. stanowi, że w sprawach $z$ zakresu ubezpieczeń społecznych niedopuszczalne jest zawarcie ugody. Przepisy z zakresu ubezpieczeń społecznych mają charakter bezwzględnie obowiązujący i nie mogą być modyfikowane przez strony ${ }^{24}$.

Istnieją rozbieżności dotyczące uznania, czy odwołanie od decyzji organu rentowego należy traktować na równi $z$ pozwem czy raczej jest to środek odwoławczy ${ }^{25}$. Przychylić należy się do poglądu, który również jest prezentowany przez Sąd Najwyższy, iż odwołanie inicjuje postępowanie przed sądem I instancji i w związku z tym należy traktować je jako pozew ${ }^{26 .}$

Kolejnym działaniem organu rentowego, pozbawionym jakichkolwiek racjonalnych oraz prawnych przesłanek, jest uchylenie decyzji na podstawie, której odmówiono prawa do przyznania jednorazowego odszkodowania ze względu na nieuznanie zdarzenia

postępowania cywilnego komentarz tom I art. 1-505 ${ }^{38}$, red. M. Mankowska, Warszawa 2015, s. 1249.

${ }^{23}$ M. Klimas, op.cit., s. 232.

${ }^{24}$ E. Stefańska, op.cit., s. 1249.

25 M. Klimas w swoim opracowaniu podaje, iż zwolennikami poglądu dotyczącego traktowania odwołania jako środka odwoławczego ze względu na nazewnictwo są J. Mazurek oraz J. Sieklucki. Natomiast zwolennikiem poglądu, iż odwołanie należy traktować jak pozew, jest J. Gudowski. Zob. M. Klimas, op.cit., s. 187.

${ }^{26}$ Zob. m.in. postanowienie $z$ dnia 17 października 2001 r., II UZ 141/00, „Orzecznictwo Sądu najwyższego Izba Pracy, Ubezpieczeń Społecznych i Spraw Publicznych" 2002, nr 19, poz. 472. 
za wypadek przy pracy ze względu na brak przyczyny zewnętrznej na podstawie art. 154 k.p.a., po przekazaniu odwołania do sądu. Przytoczony artykuł stanowi, że organ może uchylić decyzję ostateczną. Jednak decyzja, od której zostało wniesione odwołanie do sądu, nie jest decyzją ostateczną ${ }^{27}$. Dopiero w momencie prawomocnego rozstrzygnięcia sporu przez Sąd Ubezpieczeń Społecznych taką się stanie.

Ustawa systemowa nie zawiera definicji, czym jest decyzja ostateczna, dlatego też należy sięgnąć do art. $16 \S 1$ k.p.a. ${ }^{28}$, który stanowi, że decyzję, od których nie służy odwołanie w administracyjnym toku instancji lub wniosek o ponowne rozpatrzenie sprawy, są ostateczne. W zdaniu drugim ustawodawca wskazał, iż uchylenie lub zmiana takich decyzji, stwierdzenie ich nieważności oraz wznowienie postępowania może nastąpić tylko w przypadkach przewidzianych w kodeksie lub w ustawach szczególnych. Taką ustawą szczególną będzie właśnie ustawa o systemie ubezpieczeń społecznych.

Przedmiotem postępowania w przypadku wszczęcia postępowania na podstawie art. 154 k.p.a. jest sprawa uchylenia lub zmiany decyzji ostatecznej. Oznacza to, że nie jest to dalsze postępowanie w sprawie rozstrzygnięcia taką decyzją ${ }^{29}$. Analizując te słowa, należy podkreślić, iż aby wydać decyzję w takiej sytuacji, musi zostać przeprowadzone postępowanie. W związku z czym wydanie decyzji przez organ rentowy w chwili, kiedy akta sprawy wraz $\mathrm{z}$ odwołaniem znajdują się $\mathrm{w}$ sądzie, jest bezzasadne, ponieważ decyzja taka nie rozstrzyga sprawy merytorycznie, nie spowoduje zaspokojenia żądania, a ponadto organ rentowy nie dysponuje materiałem dowodowym w sprawie, który znajduje się w sądzie. Istnieje możliwość wypożyczenia akt z sądu, jednakże taką czyn-

27 Decyzją ostateczną jest decyzja, od której nie można wnieść odwołania. Zob. B. Adamiak, Zasady ogólne, w: B. Adamiak, J. Borkowski, Kodeks postępowania administracyjnego. Komentarz, Warszawa 2014, s. 93.

${ }^{28}$ Pogląd taki prezentuje Sąd Apelacyjny w Białymstoku w wyroku z dnia 14 kwietnia 2016 r., III AUa 1214/1, Lex nr 2039682.

29 A. Wróbel, Uchylenie, zmiana, stwierdzenie nieważności decyzji, w: Kodeks postępowania administracyjnego. Komentarz, red. M. Jaśkowiak, A. Wróbel, Kraków 2005, s. 915. 
ność uznać należy za bezcelową, w momencie kiedy to sam organ rentowy przekazał sprawę do sądu celem jej rozstrzygnięcia pod względem merytorycznym, ponieważ nie zgadzał się $z$ argumentacją zawartą w odwołaniu i nie widział podstaw do zmiany swojego stanowiska w trybie samokontroli. Kolejnym sformułowaniem, na jakie należałoby zwrócić uwagę, jest to, iż prowadzenie postępowania w przedmiocie uchylenia decyzji nie jest kontynuacją postępowania, a więc $\mathrm{w}$ takim stanie rzeczy organ rentowy nie ma kompetencji do prowadzenia postępowania wyjaśniającego w sprawie wypadkowej.

Ponadto na podstawie art. 110 k.p.a. organ rentowy związany jest wydaną przez siebie decyzją, a w chwili wniesienia przez stronę odwołania sprawa zaczyna być rozpatrywana pod reżimem k.p.c., nie zaś k.p.a. Związanie organu wydaną decyzją powoduje, że organ nie jest jej dysponentem, nie może jej w sposób dowolny uchylać, unieważniać czy wznawiać postępowanie celem weryfikacji danej decyzji. Dlatego też polski ustawodawca, którego racjonalność należy domniemać, w k.p.a. uregulował szczególne instytucje dotyczące uchylenia, stwierdzenia nieważności decyzji oraz wznowienia postępowania. Przewidziane tryby nadzwyczajne obwarowane są szczególnymi przesłankami, których katalog zawarty jest w postanowieniach k.p.a. oraz przepisach szczególnych. Dopiero ich zaistnienie powoduje zaktualizowanie się uprawnień organu do wszczęcia postępowania w trybie nadzwyczajnym ${ }^{30}$. Próba zaś sanowania błędu organu rentowego w postępowaniu wypadkowym nie może stanowić podstawy do wszczęcia, prowadzenia postępowania, a w konsekwencji wydania decyzji uchylającej w sprawie, która zawisła przed sądem powszechnym.

Kluczowym przepisem jest tutaj art. 83 a ust. 2 ustawy o s.u.s., który stanowi, że decyzje ostateczne ZUS, od których nie zostało wniesione odwołanie do właściwego sądu, mogą być z urzędu przez ZUS uchylone, zmienione lub unieważnione na zasadach określonych w k.p.a. ${ }^{31}$ Tak sformułowany przepis wyklucza możliwość

30 Ibidem, s. 685.

${ }^{31}$ Inny pogląd reprezentuje J. Jagielski, który uznaje, że istnienie pełnej kontroli sądów powoduje wyłączenie stosowania do decyzji przewidzianych w k.p.a. instytucji kontroli i weryfikacji decyzji, czyli instytucji uchylenia, 
uchylenia decyzji na podstawie art. 154 k.p.a. bądź zastosowania innego przepisu przewidującego wszczęcie postępowania w trybie nadzwyczajnym, po wniesieniu odwołania do sądu. Przepis ten jest normą szczególną w stosunku do norm zawartych w k.p.a., pomimo że w swojej treści odsyła do jego unormowań. Jednakże sformułowanie, zawierające istotny element, wskazuje, iż wyeliminowanie $z$ obrotu prawnego decyzji w trybach nadzwyczajnych jest możliwe wyłącznie w stosunku do decyzji, od których nie zostało wniesione odwołanie. W konsekwencji wniesie odwołania, chociażby takiego, które jeszcze nie zostało przekazane do sądu wraz $z$ aktami i nie minął 30-dniowy termin do dokonania tej czynności, powoduje, iż organ rentowy może zmienić lub uchylić zaskarżoną decyzję jedynie na podstawie art. $477^{9} \S 2$ zd. 2 i 3 k.p.c. Przepis ten stanowi, że organ rentowy przekazuje niezwłocznie odwołanie wraz $z$ aktami do sądu. Organ, jeżeli uzna odwołanie w całości za słuszne, może zmienić lub uchylić zaskarżoną decyzję. W tym przypadku odwołaniu nie nadaje się dalszego biegu. W związku $z$ tym w sprawie uchylenia decyzji, od której zostało wniesione odwołanie, podstawą prawną uchylenia będzie art. $477^{9} \S 2$ zd. 2 k.p.c., nie zaś art. 83 a ust. 2 ustawy o s.u.s. lub art. 154 k.p.a.

\section{Podsumowanie}

Podsumowując rozważania, podkreślić należy, że uznanie zdarzenia za wypadek, ponieważ zostało wywołane przyczyną zewnętrzną i spełnia łącznie wszystkie przesłanki z art. 3 ustawy wypadkowej, nie jest zaspokojeniem żądania. Dlatego też w sprawach wypadkowych niemożliwe jest uchylenie na podstawie art. $477^{9} \S 2 \mathrm{zd}$. 2 k.p.c., decyzji odmawiającej prawa do jednorazowego odszkodowania, ponieważ brak było przyczyny zewnętrznej. W sprawach wypadkowych odwołanie zawsze zawiera żądanie przyznania prawa

zmiany decyzji, stwierdzenia nieważności czy wznowienia postępowania, zob. J. Jagielski, Renty i emerytury z ubezpieczenia społecznego, „Przegląd Ubezpieczeń Społecznych i Gospodarczych” 1999, nr 6, s. 15. 
do jednorazowego odszkodowania, dlatego też organ rentowy nie będzie mógł uchylić decyzji na podstawie tego przepisu, uznając tym samym odwołanie za słuszne, gdyż w dalszym ciągu takie odszkodowanie nie będzie mogło być przyznane ze względu na brak ustalenia procentowego uszczerbku na zdrowiu.

Możliwe jest jedynie założenie, że organ rentowy uchylając decyzję, wyda w ciągu 30 dni (w trybie samokontroli), decyzję przyznająca jednorazowe odszkodowanie, po ustaleniu procentowego uszczerbku na zdrowiu przez lekarza orzecznika ZUS, w przypadku wniesienia sprzeciwu przez Komisję Lekarską ZUS. Takie założenie należy odrzucić ze względu np. na konieczność wezwania poszkodowanego na badanie.

\section{STRESZCZENIE}

Uznanie zdarzenia za wypadek przy pracy przez organ rentowy w sprawie zawisłej przed sądem powszechnym

Niniejszy artykuł ma na celu przedstawienie problematyki wypadków przy pracy, lecz jego istota różni się od dotychczasowych publikacji na ten temat. Zazwyczaj podejmując problematykę wypadków przy pracy, autorzy skupiają się na definicji ustawowej oraz poszczególnych przesłankach wchodzących w jej skład. Owszem definicja, która jest zupełnie odmienna od potocznego znaczenia tego słowa w języku polskim, często nastręcza w praktyce wiele problemów. Nad tą problematyką pochylał się już wielokrotnie Sąd Najwyższy. Również wiele problemów w praktyce Zakładu Ubezpieczeń Społecznych sprawia postępowanie sądowe z zakresu ubezpieczeń społecznych, w szczególności chodzi tutaj o rolę, jaką odgrywa organ rentowy, który staje się stroną postępowania, a nie jego gospodarzem. Dlatego też jego uprawnienia i obowiązki nie wynikają z przepisów kodeksu postępowania administracyjnego, lecz z przepisów kodeksu postępowania cywilnego oraz ustawy o systemie ubezpieczeń społecznych. Niestety praktyka pokazuje zupełnie inną rzeczywistość niż ta, którą uregulował ustawodawca.

Słowa kluczowe: wypadek przy pracy; przyczyna zewnętrzna; jednorazowe odszkodowanie; organ rentowy; postępowanie sądowe 


\title{
SUMMARY
}

\author{
Recognition by a pension body of an event \\ as an accident at work in a case pending \\ before a common court
}

\begin{abstract}
The aim of this article is to present the issue of accidents at work, but essence is different from previous publications on this subject. Usually taking the problem of accidents at work, the whole subject is focused on the enactment definition and individual premises. The definition, which is quite different from the ordinary meaning in Polish, causes many problems in practice. That definition has been examined many times by the Supreme Court. Also a lot of problems in the practice of the Social Insurance makes judicial proceedings, related to social security, in particular a question of pension body's relevance. Therefore, his rights and obligations also do not arise from provisions of the Code of the Administrative Procedure, but from provisions of the Code of Civil Procedure and laws of Social Insurance system. Unfortunately, the proceedings in fact differs from imposed by the legislature.
\end{abstract}

Keywords: accident at work; external reason; single damages; pension body; judicial proceedings

\section{BIBLIOGRAFIA}

Adamiak B., Borkowski J., Kodeks postępowania administracyjnego. Komentarz, Warszawa 2014.

Babińska R., Wzruszalność prawomocnych decyzji rentowych, Warszawa 2007.

Gersdorf M., Gudowska B. (red.), Społeczne ubezpieczenia wypadkowe i chorobowe, Warszawa 2012.

Jagielski J., Renty i emerytury z ubezpieczenia społecznego, „Przegląd Ubezpieczeń Społecznych i Gospodarczych” 1999, nr 6.

Jaśkowiak M., Wróbel A., Kodeks postępowania administracyjnego. Komentarz, Kraków 2005.

Klimas M., Postępowanie sądowe $w$ sprawach z zakresu ubezpieczeń spoŁecznych, Warszawa 2013. 
$370 \quad$ Karolina Ziółkowska

Lach D. E., Samol S., Ślebzak K., Ustawa o ubezpieczeniu społecznym $z$ tytułu wypadków przy pracy i chorób zawodowych. Komentarz, Warszawa 2010.

Manowska M. (red.), Kodeks postępowania cywilnego komentarz tom I art. 1-505 38 , Warszawa 2015.

Wantoch-Rekowski J. (red.), Ustawa o systemie ubezpieczeń społecznych, Warszawa 2014. 